\title{
Determinants of FDI in Sub-Saharan African Countries: A Review of the Evidence
}

\author{
Lateef Ademola Olatunji \\ Federal Polytechnic, Offa. Kwara State, Nigeria \\ Muhammad Sadiq Shahid \\ IMS, BZU Multan, Pakistan
}

Received: September 10, 2015 Accepted: September 30, 2015

doi:10.5296/ber.v5i2.6291

URL: http://dx.doi.org/10.5296/ber.v5i2.6291

\begin{abstract}
Although it may seem natural to argue that foreign direct investment (FDI) can convey great advantages to host countries. This paper finds that FDI flows to Sub-Saharan Africa economies unaffected by conflict and political instability exceed those with crisis. For FDI to strive in these countries, it must introduce sound economic policies and make the country investor friendly. There must be political stability, sound economic management and well developed infrastructure.
\end{abstract}

Keywords: Foreign direct investment, Developed Economies, Sub-Saharan Africa

\section{Introduction}

There are many studies on the theoretical and a large inconclusive econometric literature on the determinants of FDI in Africa (Anyanwu, 2011; Alfaro, 2004; Asiedu, 2003; Morisset, 2000). These studies emphasized, among others, governance failures, problems of policy credibility, macroeconomic policy failures and poor liberalization policies as deterrents to FDI flows in African countries. The vast literature on FDI identifies a number of reasons for firms investing across national boundaries. Recently, Olatunji \& Shahid (2015) found a short-run dynamic relationship between FDI and economic growth, where they suggested that the long-run relationship can be achieved through infrastructure development and political stability in these countries. It is difficult in reality in many countries to isolate the different motives, as one motive may overlap into another. The literature on FDI identifies at least four 
different motives for firms to invest across national borders (UNCTAD, 1998). These are:

Natural resource-seeking investment, which aims to exploit the natural resource endowments of countries. Companies extracting oil (in Nigeria), gold (in Ghana) and diamond (in Botswana) belong to this category.

Market-seeking investment, which aims to access new markets that are attractive as a result of their size, growth or combination of both.

Efficiency-seeking investments, which aim to take advantage of special features in certain areas such as the costs of labour, the skills of the labour force, and the quality and efficiency of infrastructure.

Strategic-asset seeking investment is oriented towards man-made assets, as embodied in a highly-qualified and specialized workforce, brand names and images, shares in particular markets, etc. Increasingly, such FDI takes the form of cross-border mergers and acquisitions, whereby a foreign firm takes over the entire or part of domestic company that is in possession of such assets.

This study on the determinants of foreign direct investment in Sub-Sahara Africa is important for several reasons. First, a number of countries in this region that attract FDI have not been studied. It would be very useful to know why FDI flows to some countries and not to others. This study assumes added relevance given that FDI is seen as a catalyst element for Sub-Sahara Africa's new growth and development strategy. Second, it would be useful to know if different factors work differently in different countries. Third, it is important to know if indeed policy matters very much in attracting FDI in the selected African countries.

The broad objective of this chapter is to analyze the recent trends of foreign direct investment into Sub-Saharan Africa and examines some theoretical perspectives of the factors driving FDI inflows into those regions. The paper is organized as follows: Section II presents the trends in Global FDI. Section III provides the theoretical framework for the Determinants of FDI. Section IV analyses the experiences of ten Sub-Saharan African countries in attracting FDI. We conclude the paper in section $\mathrm{V}$ with some policy implications that arise from our analysis

\section{Trends in Global FDI Flow}

In 2011, FDI inflows increased in all major economic groups, developed, developing and transitional economies as shown in (Table 1) below, revitalizing the long and contentious debate about the costs and benefits of FDI inflows. On one hand, many would argue that, given appropriate policies and basic level of development, FDI can play a key role in the process of creating a better economic environment. On the other hand, potential drawbacks do exist, including a deterioration of the balance of payments, as profits are repatriated having negative impacts on competition in national markets. 
Table 1. FDI inflows, by Region, 2005-2011 (US\$ billion)

\begin{tabular}{|l|c|c|c|c|c|}
\hline Region & 2007 & 2008 & 2009 & 2010 & 2011 \\
\hline World & 2100 & 1771 & 1197.8 & 1309.0 & 1524.4 \\
\hline Developed Economies & 1444 & 1018 & 606.2 & 618.6 & 749.9 \\
\hline Developing Economies & 565 & 630 & 519.2 & 616.7 & 684.4 \\
\hline Africa & 63 & 72 & 52.6 & 43.1 & 42.7 \\
\hline East and South-East Asia & 259 & 262 & 206.6 & 294.1 & 335.5 \\
\hline South Asia & 91 & 123 & 42.4 & 31.7 & 38.9 \\
\hline West Asia & 79 & 90 & 66.3 & 58.2 & 48.7 \\
\hline Latin America \& Caribbean & 164 & 183 & 149.4 & 187.4 & 217.0 \\
\hline Transition economies & 91.0 & 123.0 & 72.4 & 73.8 & 92.2 \\
\hline
\end{tabular}

Source: UNCTAD, FDI/TNC Data Base, 2012 (www.unctad.ord/Fdistatistics)

Developing countries accounted for 45 percent of global FDI inflows in 2011. The increase was driven by East and South-East Asia and Latin America. East and South Asia still accounted for almost half of the FDI in developing economies. The FDI as percentage of GDP (see Figure 1) show, Africa has never been major recipients of FDI flows and lags behind other regions of the world. After reaching a low on the average during the 1970s and 1980s, FDI as percentage of GDP improved continuously since the mid-1990s to reach an average level of 2.2 percent after 2000 demonstrating a more pronounced role for FDI on the African continent.

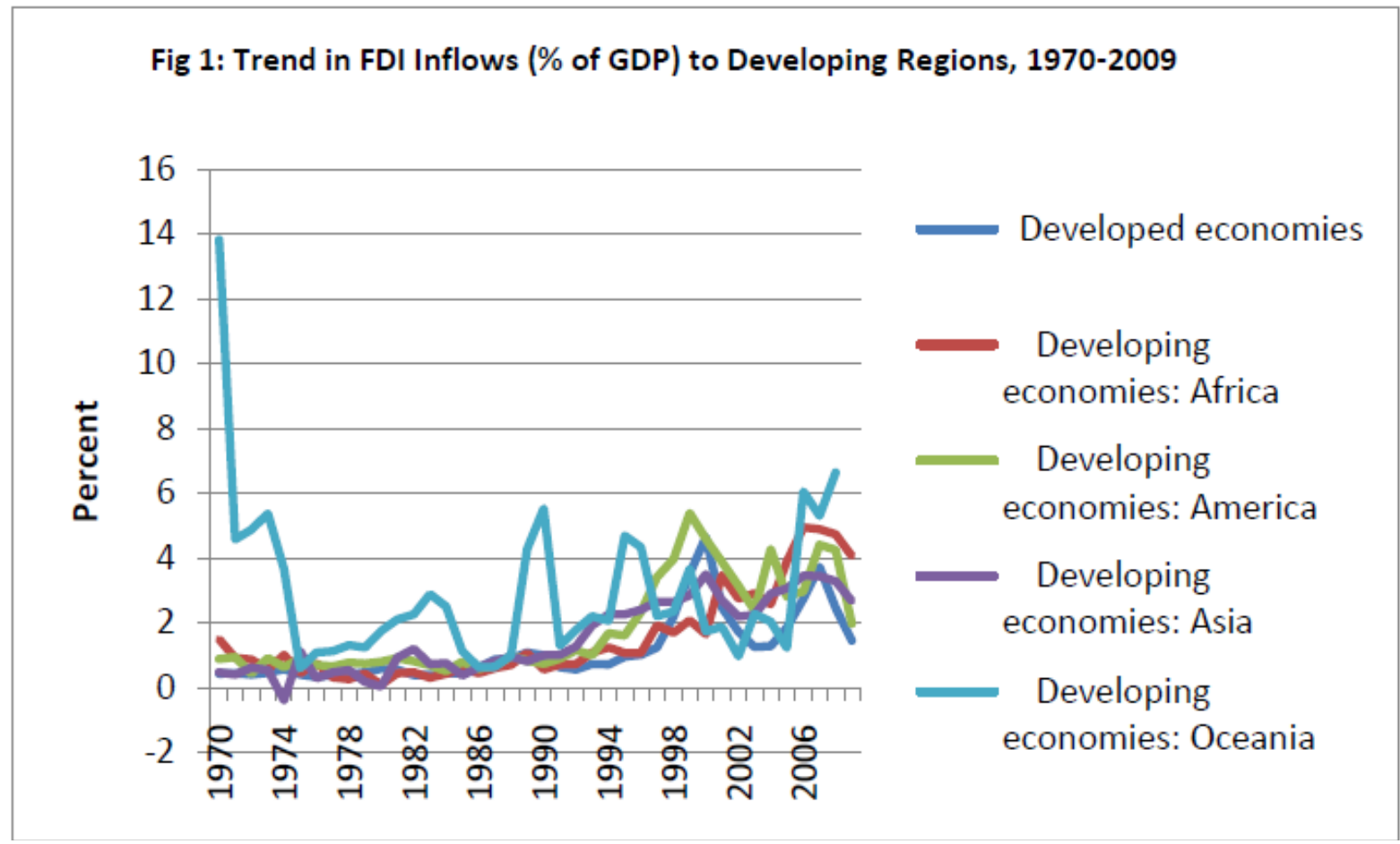

However the inflows to Africa in 2011 decreased for the third consecutive year to an estimated $\$ 42.7$ billion. This is in stark contrast to the general recovery of global FDI that resulted in a further decrease of Africa's share of the world total of 3.3 percent in 2010 to 2.8 


\section{Ml Macrothink}

percent in 2011as shown in (Table 2) below:

Table 2. Percentage Share in World FDI flows, 2007-2011

\begin{tabular}{|l|l|l|l|l|l|}
\hline Region & 2007 & 2008 & 2009 & 2010 & 2011 \\
\hline Developed Economies & 68.8 & 57.5 & 50.6 & 47.3 & 49.1 \\
\hline Developing Economies & 26.9 & 35.6 & 43.3 & 47.1 & 44.9 \\
\hline Africa & 3.0 & 4.1 & 4.4 & 3.3 & 2.8 \\
\hline East and South-East Asia & 12.3 & 15.9 & 17.2 & 22.5 & 22.0 \\
\hline West Asia & 3.7 & 5.1 & 5.5 & 4.4 & 3.2 \\
\hline Transition economies & 4.3 & 6.9 & 3.5 & 2.4 & 2.6 \\
\hline
\end{tabular}

Source: UNCTAD, FDI/TNC Data Base, 2012 (www.unctad.org/Fdistatistics)

By 1990, Africa's share was a mere 1.37 percent compared to Asia's 10. 9 percent and by 2009 while Africa's share was just 5.27 percent, Asia received a whopping 27 percent (see Figure 2).

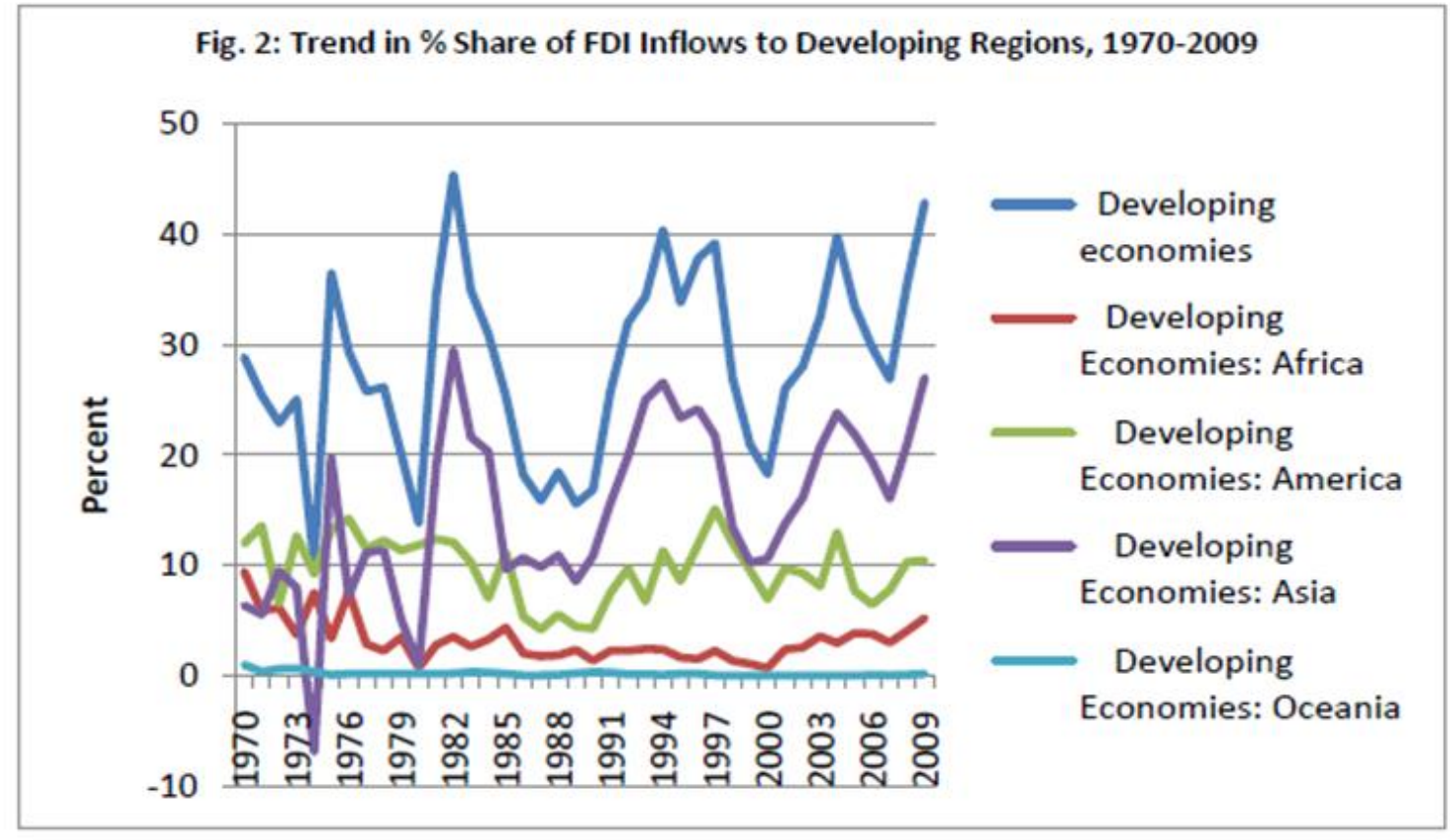

Source: UNCTAD, FDI/TNC Data Base, 2012

This near stagnation is the result of economic and political uncertainty in Egypt, Libya and Tunisia. FDI flows to Africa countries increased in 2010, as shown in Table 3 below 
Table 3. Regional Trends of FDI inflows and inflows (US\$ Billions)

\begin{tabular}{|l|c|c|c|c|}
\hline Region & \multicolumn{2}{|c|}{ FDI inflows } & \multicolumn{2}{c|}{ FDI outflows } \\
\hline & 2009 & 2010 & 2009 & 2010 \\
\hline Africa & 60.2 & 55.0 & 5.6 & 6.6 \\
\hline North Africa & 18.5 & 16.9 & 2.5 & 3.4 \\
\hline East Africa & 3.6 & 3.7 & 0.1 & 0.2 \\
\hline West Africa & 12.7 & 11.3 & 1.5 & 1.1 \\
\hline Southern Africa & 20.0 & 15.1 & 1.4 & 1.9 \\
\hline Central Africa & 5.4 & 8.0 & 0.1 & 0.1 \\
\hline
\end{tabular}

Source: World Investment Report, 2011

Over the past five years, SSA Africa FDI has been driven strongly by commodity related investments. Nigeria accounted for 79\% of total FDI in the region in 2005. However, Nigeria's share of regional investment has fallen to about $54 \%$ as Ghana's new oil industry is attracting an increasing share, rising from $\$ 860$ million in 2007 to $\$ 1.67$ billion in 2011 (UNCTAD, 2012).

Generally, the last decade has witnessed a significant decrease in the flow of foreign direct investment in Sub-Saharan African countries. Middle-income countries have benefited at the expense of lower-income countries. In spite of policy initiatives in a number of SSA countries and the significant improvements in the factors governing FDI-including but not limited to economic reform, democratization, privatization, enduring peace and stability-FDI inflows to these countries still lag behind those of other regions of the world. Many explanations have been given in the literature for this small share in the global FDI flows. The myriad of explanations varies from bias against Africa because of its risks, inappropriate environment, political instability, governance failures, and problems of policy credibility, macroeconomic policy failures and poor liberalization policies as deterrents to FDI flows.

\section{Theoretical Framework for the Determinants of FDI}

The determinants of foreign direct investment inflows continue to engage academics' and policy makers' attention, the absence of a generally accepted theoretical framework has led researchers to rely on empirical evidence for explaining the emergence of FDI. Although there has been considerable theoretical work on foreign direct investment (Hymer, 1960; Caves, 1982; and Ajayi, 2006), there is no agreed model providing the basis for empirical work. A popular conceptualization of, and theoretical framework for, FDI determinants is the "eclectic paradigm" attributed to Dunning (1993). It provides a framework that groups' micro and macro level determinants in order to analyze why and where multinational companies (MNCs) invest abroad. The framework posits that firms invest abroad to look for three types of advantages: Ownership (O), Location (L), and Internalization (I) advantages; hence it is called the OLI framework. The ownership-specific advantages allow a firm to compete with others in the markets it serves regardless of the disadvantage of being foreign because it is 
able to have access to, and exploit and export natural resources and resource-based products that are available to it. The location advantages are those that make the chosen foreign country a more attractive site (such as labour advantages, natural resources, trade barriers that restrict imports, gains in trade costs and strategic advantages through intangible assets). The location advantages may arise from differences in country natural endowments, government regulations, transport costs, macroeconomic stability, and cultural factors. Internalization advantages arise from exploiting imperfections in external markets, including reduction of uncertainty and transaction costs in order to generate knowledge more efficiently as well as the reduction of state-generated imperfections such as tariffs, foreign exchange controls, and subsidies. Following on these, Dunning (1997) identified four categories of motives for FDI: resource seeking (to access raw materials, labour force, and physical infrastructure resources); market seeking (horizontal strategy to access the host-country domestic market); efficiency seeking (vertical strategy to take advantage of lower labour costs, especially in developing countries); and strategic-asset seeking (to access research and development, innovation, and advanced technology) (Cleeve, 2008).

The literature on the forces driving FDI has also identified both policy and non-policy factors as drivers of FDI (Fedderke and Romm, 2006). Policy factors include openness, product-market regulation, labour market arrangements, corporate tax rates, direct FDI restrictions, trade barriers, and infrastructure. Non-policy factors include market size of the host country (often measured by the GDP), distance/transport costs, factor proportions (or factor endowments) and political and economic stability. Gottschalk (2001) and Calvo et al. (1996) present a two-factor classification of the factors that influence FDI flows into developing countries as push and pull factors. The push factors, which are external to developing countries, focus on growth and financial market conditions in industrial countries, while the pull factors determine their allocation among less developed countries in terms of economics, social-political, and uncertainty in those countries.

A similar classification has emerged from the works of Tsai (1991), Ning and Reed (1995) and Lall et al. (2003) who sees these factors as (i) those on the supply side (e.g., skilled labour, research and development, and infrastructure), (ii) those on demand side (host country economic and social variables or pull factors, including interest rates, tax and tariff levels, market size, wage rates, income distribution, human capital, cost differentials, exchange rates, fiscal policies, trade policies, physical and cultural distance among others); and (iii) institutional factors (culture, intellectual property rights, transaction costs, political risk, corruption, and bureaucracy).

Sekkat and Veganzones-Varoudakis (2007) have grouped the factors determining the inward flow of FDI into three categories: basic economic factors, trade and exchange market policies, and other aspects of the investment climate. The basic economic factors include the difference in the rate of return on capital across countries, portfolio diversification strategy of investors and market size of the host country. Trade and foreign exchange policy considerations relate to trade liberalization and exchange rate movements and their volatility. Business climate factors relate to infrastructure (Wheeler and Mody, 1992), labour costs and availability of skilled labour, incentive factors, political risk, economic factors, political 
stability (the number of constitutional changes in government leadership), the role of institutions in terms of commitments to enforcement of rules.

\section{Determinants of FDI in SSA: Cross Country Evidence Overview}

In this section, we seek to provide an explanation for why some countries in Sub-Saharan Africa have succeeded in attracting fairly large amounts of foreign investment, while others have not. The analysis is confined to case studies, because the availability of reliable and consistent data on FDI and of adequate information on the policies implemented to promote FDI is relatively limited for various African countries. An attempt has also been made to focus attention on countries that have been successful in obtaining reasonable amounts of FDI that is diversified across the various sectors of the economy.

The last decade has been marked by increasingly diverging trends in the FDI performance of individual countries, while some countries have experienced substantial increases in FDI inflows, others have stagnated or even suffered net investment. Traditionally, most of the FDI in Sub-Sahara Africa countries originated in a few countries of Western Europe and in the United States. France, Germany, the United Kingdom and the United States accounted for the lion's share of total inflows from the member countries of the Organization for Economic Co-operation and Development to Sub-Saharan Africa in 1983-1987 (UNCTAD, 1998). And recently, within the group of OECD countries such as Canada, Italy and the Netherlands, and to some extent Norway, Portugal and Spain have emerged as important sources of FDI in Africa over the past 10 years. These six countries increased their share in African inflows from 8 percent to more than 22 percent, making up for the decline share of some traditional home countries such as Japan and the United Kingdom.

Contrary to common perception, FDI in Africa is no longer concentrated in the primary sector. Even in oil-exporting countries, services and manufacturing are key sectors for FDI. For example the primary sector accounted for only a little over 30 percent of the FDI stock in Nigeria in 1992, while manufacturing accounted for almost 50 percent and services close to 20 percent (UNCTAD, 1997). Mauritius is another example of an African country that has managed, particularly since the beginning of the 1980s, to increase significantly the amount of FDI going into manufacturing industries such as textiles and electronic equipment (UNCTAD, 1998).

A large share of FDI in Sub-Saharan Africa has been in countries that have abundant natural resources. It is in mining of high-value, minerals and petroleum where Sub-Saharan Africa is particularly prominent as a host to FDI and where great potential for future FDI exists. In terms of the volume of FDI received, Angola, Botswana, Cote d'voire, and Nigeria have consistently been among the top ten countries in Africa. While there are quite a few countries abundant in some type of natural resources, only some have been successful in obtaining diversified FDI. We analyze the experience of ten Sub-Saharan African countries in attracting FDI.

Botswana's ecology is very delicate with only 5 percent of the land being arable and inadequate availability of water being a perennial constraint, agriculture-based growth is 
almost impossible, and the country has been forced to rely on its mining sector to generate economic growth. It resource endowment comprises mainly of diamonds in the Kalahari Desert, copper deposits at Selebi-Phikwe, coal, and soda ash. The mining sector accounts for more than 50 percent of GDP, government revenues from mineral taxes and royalties account for more than 50 percent of total revenue intake, and diamond exports account for almost 75 percent of total exports. Relying on FDI for the development and export of its natural resources, Botswana advanced from the group of the world's poorest countries at its independence to the group of middle-income countries by 1990. The GDP growth has averaged about 7 percent per annum between 1985 and 1999.

Namibia is endowed with substantial natural resources. The country is among the top twenty mining countries in the world, with diamonds and uranium ore being the leading commodities. Besides mining, the country derives significant growth from marine fishing and agriculture, both of which serve as important sources of exports. Relative to other countries in Africa, Namibia is a reasonably rich country with an average per capita income of around US $\$ 2,000$, although income distribution is highly skewed. GDP growth has averaged about 5.5 percent per annum between 1985 and 1999. FDI inflows to Namibia have increased significantly over the past few years-averaging about 4 percent of GDP per year in the second half of the 1990s.

In Lesotho, a rather robust overall macroeconomic situation through most of the 1990s has contributed to economic stability, which in turn has been partially responsible for political and social stability. The manufacturing sector's contribution to GDP has increased from an average of 12.5 percent in 1991-1995 to about 15 percent in the period thereafter. Almost 30.5 percent of total value added in this sector originates in textiles and clothing, where most of the FDI coming from South Africa and the Far East has concentrated. Labour-intensive manufacturing of textiles, leather goods, electronics, and light-manufactured products has also increased rapidly.

Economic development in Swaziland, a small country with a population of about 1.4 million and bordered on three sides by South Africa, is largely determined by developments in the agriculture and manufacturing sectors, whose combined share averaged about 48 percent of GDP in 1990-1995. As a result of the limited size of the local market, the bulk of the output from the agriculture and the manufacturing sector is exported, while a considerable share of inputs and final consumption goods are imported. Four export industries specializing in processing agricultural and forestry products, that include wood pulp production, soft drink concentrate, fruit canning, and sugar processing, dominate the manufacturing sector. The Swazi economy has remained closely linked to that of South Africa, which accounts for some 90 percent of Swaziland's imports and about 75 percent of its exports.

At independence, the Mauritian economy was almost entirely reliant on sugar. In contrast to most countries in Africa, the absence of mineral resources necessitated significant investment in human capital to achieve economic progress. Sustained policies of economic diversification, liberalization, and export orientation, coupled with the country's political stability and bilingual labour force, have succeeded in attracting foreign investment. Real GDP growth averaged 6 percent per annum between 1985 and 1999. Economic growth is 
currently well balanced around four main sectors of the economy, namely agriculture, led by the sugar industry, tourism, manufacturing for export, mainly through EPZs, and more recently, offshore financial services. Inflation rate in the country has been committed to single digits for many years.

Mozambique has benefited from political stability, following the end of the civil war. It has allowed policy makers to focus attention on measures to promote macroeconomic stability, achieve rapid economic growth and alleviate widespread poverty. Economic growth has averaged about 8.5 percent per annum in 1995-99, while inflation, which averaged about 75 percent annum in the eighties, has declined to single digits in recent years. A significant reduction in the government's fiscal deficit, allowing an improvement in the external current account, reflects the government's long-term commitment to macroeconomic stability and a market-friendly environment for investors to do business. The exchange rate has appreciated and has remained relatively stable over the past few years.

South Africa is one of the major destinations of foreign direct investment in Africa. The bulk of foreign investments into South Africa have been market-seeking, as evidenced by the concentration in manufacturing, financial services, telecommunications, and food and beverages. The attractiveness of South Africa as an investment destination is hinged on the commitment to sound macroeconomic stability and market-friendly environment for investors to do business. This trend not withstanding, South Africa has attracted less FDI than its global share of GDP would suggest.

Available data suggest that Nigeria was the second largest FDI recipient in Africa in 2012. Traditionally, the FDI has concentrated in the extractive industries, mainly oil, but there has been a diversification into manufacturing sector in recent years. While the FDI regime in Nigeria is improving, serious deficiencies remain. Political and institutional uncertainty persists in Nigeria and the weakening of the rule of law has discouraged FDI and trade flows outside the oil sector. Legal and judicial systems are inadequate to support the needs of new investors into other sectors of the economy. Addressing problems related to corruption, inadequate infrastructure and inconsistent regulations remains the key element of the country's future prospects of attracting more efficiency-seeking FDI. There is a need for a proactive policy towards FDI that involves upgrading of national laws and incentives that are in conformity with international practices.

Ghana, being a small developing African country, has attracted the non-marketing seeking type of FDI. The major categories of FDI attracted into Ghana have been lured by natural resources and actively promotional campaigns, plus structural reforms and privatizations. The mining sector, mainly gold, has become almost synonymous with FDI in Ghana, but it gradually deteriorated prior to the Economic Recovery Program (ERP). The several reasons identified for this include shortages of foreign exchange to maintain and rehabilitate the mines; lack of capital investments for exploration and development; poor management and lack of mining skills; infrastructure deterioration.

FDI flows in Kenya have been volatile. In the period 1977-2001, FDI was about $0.6 \%$ of GDP, a ratio that was below the African average of $1.9 \%$. Since the $1980 \mathrm{~s}$, the country has faced 
declining net inflows compared with neighbouring countries like Uganda and Tanzania. In 2001, Kenya had about 114 multinational corporations (MNC) affiliates; many of them in both the industrial and tertiary sectors with others attracted by the natural resources especially those in the agro-industry and the cement industry.

\section{Concluding Observations}

It may be noted that there are many countries in Sub-Saharan Africa today that are in the same stage of development that some of the countries in Asia were prior to their rapid rise to economic growth and prosperity. For example, GDP per capita in Korea, Malaysia, the Philippines, and Thailand was in the range of US\$200-US\$400 in 1970. This compares with the current levels in many of the countries in Africa. Similarly, some of the social indicators relating to education and health indicate that some African countries, including Ghana, Tanzania, Zambia and Zimbabwe, are better placed than some of the Asian countries prior to their take-off. So what can countries in Africa do to replicate the phenomenal export-and investment-led growth achieved by the Asian nations?

While Africa is undoubtedly a region rich in natural resources, it is quite clear from the above analysis that a critical mass of mutually reinforcing measures needs to be in place before countries in Africa can secure a larger share in global FDI flows. Progress towards conflict resolution is essential, because an important determinant of investment location is political stability. Political stability is however, a necessary, though not a sufficient condition to ensure access to large FDI lows. Within Sub-Saharan Africa, and in other regions of the world, political stability in tandem with macroeconomic stability has been the key to attracting FDI.

In terms of lessons from Sub-Saharan Africa countries, the following are identified as important factors in attracting FDI: A predictable and consistent policy and macroeconomic environment; successful implementation of privatization; efforts at regional integration, which is important in attracting market-seeking investments; aggressive investment promotion; good infrastructural facilities and sound human capital development.

\section{References}

Ajayi, S. I. (2003). What Africa needs to do to benefit from globalization. Finance and Development, 38(4), 6-8

Ajayi, S. I (2006). Foreign Direct Investment in Sub-Saharan Africa: Origins, Targets, Impact and Potential. African Economic Research Consortium, Nairobi, Kenya

Alfaro, L. (2003). Foreign Direct Investment and Growth: Does the Sector Matter? Harvard Business School Finance Working Paper, Harvard University

Asiedu, E. (2006). Foreign direct investment in Africa: The role of natural resources, market size, government policy, institutions and political instability.The World Economy, 29(1), 63-77. http://dx.doi.org/10.1111/j.1467-9701.2006.00758.x

Asiedu, E. (2002). On the Determinants of Foreign Direct Investment to Developing Countries: Is Africa Different? World Development, 30(1), 107-119. 
http://dx.doi.org/10.1016/S0305-750X(01)00100-0

Anyanwu, J. C. (2011). Determinants of Foreign Direct Investment Inflows to Africa, 1980-2007, Working Paper Series No. 136, African Development Bank, Tunis, Tunisia

Baniak, A., Cukrowski A. J., \& Herczynski, J. (2005). On the Determinants of Foreign Direct Investment in Transitional Economies. Problems of Economic Transition, 48(2), 6-28.

Calvo, G. A., Leiderman, L., Reinhart, C. M. (1996). Inflows of Capital to Developing countries in the 1990s. Journal of Economic Perspectives, 10(2), 123-139 http://dx.doi.org/10.1257/jep.10.2.123

Caves, R. E. (1982). Multinational Enterprises and Economic Analysis, Cambridge and New York: Cambridge University Press.

Cleeve, E. (2008). How Effective Are Fiscal Incentives to Attract FDI to Sub-Saharan Africa?", The Journal of Developing Areas, 42(1), 135-153. http://dx.doi.org/10.1353/jda.0.0015

De Mello, L. R. (1997). Foreign direct investment in developing countries and growth: A selective survey. Journal of Development Studies, 34(1), 1-34. http://dx.doi.org/10.1080/00220389708422501

Dunning, J. H. (1993). Multinational Enterprises, and the Global economy, Addison Wesley, Wokingham

Dunning, J. H. (1977). Trade, location of economic activity and the MNE: a search for an eclectic approach in B. Ohlin and P.O. Hesselborn (eds.) The International Allocation of Economic Activity, London, Macmillan, 395-418.

Fedderke J. W., and Romm A. T. (2006). Growth impact and determinants of foreign direct investment into South Africa, 1956-2003. Economic Modeling, 23, 739-760. http://dx.doi.org/10.1016/j.econmod.2005.10.005

Gottschalk, R. (2001). Lenders and Investors' International Portfolio Decisions: What Do we know? Institute of Development Studies, Sussex

Hymer, S. (1960). The International Operations of National Firms: A study of Foreign Direct Investment and challenge of Development. New York and Geneva: United Nations.

Lall, P., Norman, D. W., \& Featherstone, A. M. (2003). Determinants of US Direct Foreign Investment in the Caribbean. Applied Economics, 35(13), 1485-1496. http://dx.doi.org/10.1080/0003684032000100382

Morisset, J. (2000). Foreign Direct Investment in Africa- Policies also Matter. Transnational Corporation, 9(2), pp. 107-125

Ning, Y. Reed, M. R. (1995). Locational Determinants of the US Direct Foreign Investment in Food and Kindred Products. Agribusiness: An International Journal, 11, 77-85. http://dx.doi.org/10.1002/1520-6297(199501/02)11:1<77::AID-AGR2720110108>3.0.CO;2- 
0

Olatunji, L. A., \& Shahid, M. S. (2015). FDI and Economic Growth in Nigeria: A Co-integration Analysis. Business and Economic Research, 5(1), 243-261. http://dx.doi.org/10.5296/ber.v5i1.6647

Sekkat, K., \& Veganzones-Varoudakis, M. A. (2007). Openness, Investment Climate, and FDI in Developing Countries. Review of Development Economics, 11(4), 607-620. http://dx.doi.org/10.1111/j.1467-9361.2007.00426.x

Tsai, P. (1994). Determinants of Foreign Direct Investment and its Impact on Economic Growth. Journal of Economic Development, 19(1), 137-63.

UNCTAD (1998), foreign direct investment in Africa: Performance and potential. New York: United Nations Publication.

UNCTAD (1999), foreign direct Investment in Africa: Performance and potential. New York: United Nations Publication

UNCTAD (2005), Economic Development in Africa: Rethinking the role of Foreign Direct Investment. Geneva: United Nations Conference on Trade and Development

UNCTAD (2010a), World Investment Report 2010-Investing in a Low-Carbon Economy, United Nations Conference on Trade and Development: Geneva

UNCTAD (2010b), Regional Trends: Africa, World Investment Report 2010-investing in a Low-Carbon Economy, United Nations Conference on Trade and Development: Geneva

Wheeler, D. \& Mody, A. (1992). International Investment Location Decision: the case of United-States Firms. Journal of International Economics, 33(1-2), 1992. 55-76. http://dx.doi.org/10.1016/0022-1996(92)90050-t

World Economic Forum (1997). The Global Competitiveness Report 1997, Geneva World Economic Forum

World Economic Forum (1998a). Africa Competitiveness Report 1998, Geneva: World Economic Forum.

World Investment Report (1998-2001), United Nations Conference on Trade and Development, New York

\section{Copyright Disclaimer}

Copyright for this article is retained by the author(s), with first publication rights granted to the journal.

This is an open-access article distributed under the terms and conditions of the Creative Commons Attribution license (http://creativecommons.org/licenses/by/3.0/). 